\title{
Evaluation of Toxicity and Gene Expression Changes Triggered by Oxide Nanoparticles
}

\author{
Pooja Dua, ${ }^{\dagger, \text {,a }}$ Kiran N. Chaudhari, ${ }^{\S, a}$ Chang Han Lee, ${ }^{\dagger}$ Nitin K. Chaudhari, ${ }^{\S}$

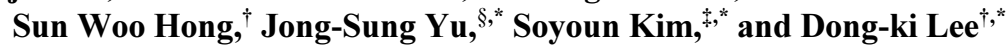 \\ ${ }^{\dagger}$ Global Research Laboratory for RNAi Medicine, Department of Chemistry and BK21 School of Chemical Materials Science, \\ Sungkyunkwan University, Suwon 440-746, Korea. *E-mail: dklee@skku.edu \\ ${ }^{\star}$ Department of Biomedical Engineering, Dongguk University, Seoul 100-715, Korea. E-mail: skim@dongguk.edu \\ ${ }^{\S}$ Department of Advanced Materials Chemistry, BK21 Research Team, Korea University, Chungnam 339-700, Korea \\ E-mail: jsyu212@korea.ac.kr \\ Received January 10, 2011, Accepted April 25, 2011
}

\begin{abstract}
Several studies have demonstrated that nanoparticles (NPs) have toxic effects on cultured cell lines, yet there are no clear data describing the overall molecular changes induced by NPs currently in use for human applications. In this study, the in vitro cytotoxicity of three oxide NPs of around $100 \mathrm{~nm}$ size, namely, mesoporous silica (MCM-41), iron oxide ( $\mathrm{Fe}_{2} \mathrm{O}_{3}-\mathrm{NPs}$ ), and zinc oxide ( $\mathrm{ZnO}-\mathrm{NPs}$ ), was evaluated in the human embryonic kidney cell line HEK293. Cell viability assays demonstrated that $100 \mu \mathrm{g} / \mathrm{mL}$ MCM-41, $100 \mu \mathrm{g} / \mathrm{mL}$ $\mathrm{Fe}_{2} \mathrm{O}_{3}$, and $12.5 \mu \mathrm{g} / \mathrm{mL} \mathrm{ZnO}$ exhibited $20 \%$ reductions in HEK293 cell viability in 24 hrs. DNA microarray analysis was performed on cells treated with these oxide NPs and further validated by real time PCR to understand cytotoxic changes occurring at the molecular level. Microarray analysis of NP-treated cells identified a number of up- and down-regulated genes that were found to be associated with inflammation, stress, and the cell death and defense response. At both the cellular and molecular levels, the toxicity was observed in the following order: $\mathrm{ZnO}-\mathrm{NPs}>\mathrm{Fe}_{2} \mathrm{O}_{3}-\mathrm{NPs}>\mathrm{MCM}-41$. In conclusion, our study provides important information regarding the toxicity of these three commonly used oxide NPs, which should be useful in future biomedical applications of these nanoparticles.
\end{abstract}

Key Words : MCM-41, $\mathrm{Fe}_{2} \mathrm{O}_{3}$ nanoparticle, $\mathrm{ZnO}$ nanoparticle, HEK293, Microarray

\section{Introduction}

Nanoparticles (NPs) have increased surface area to weight ratios relative to the same materials in the non-nano size range. In addition to unusual physical properties, NPs are also more chemically reactive than larger particles, which can be either advantageous or harmful depending on their end use. The nanotech boom started around a decade ago and since then the use of NPs in consumer goods and biomedical applications has dramatically increased. NPs are increasingly applied as drug delivery vehicles, biosensors, imaging contrast reagents, and therapeutic agents. However, it is surprising that even today the scientific and industrial community has no sufficiently clear data on the overall effects of these NPs on human health.

NPs are easily internalized into cells ${ }^{1,2}$ and some NPs have even been shown to cross the blood brain barrier ${ }^{3-5}$ where they alter biological processes and cause toxicity. Various in vitro and in vivo studies indicate that some NPs are associated with serious toxicity issues. The most commonly used in vitro toxicity tests focus on whether potentially toxic agents result in cell death. However, sublethal cellular changes may also exist that are not visible in such toxicity screens, but may significantly affect biological processes at

\footnotetext{
${ }^{\mathrm{a}}$ These authors contributed equally to this work
}

the organismal level. Hence, it is important to identify overall cellular changes mediated by NP exposure. Identification of molecular signatures of toxicity at the genomic or proteomic levels provides comprehensive and reliable high throughput data. These data can then be used to compare, classify, and grade a NP on a scale of toxicity. In the present study we identified the molecular signatures of toxicity associated with commonly used oxide NPs. We evaluated and compared three NPs, mesoporous silica, iron oxide and zinc oxide (all around $100 \mathrm{~nm}$ in size), in terms of toxicity on HEK293 human embryonic kidney fibroblast cells using a cell death assay and DNA microarray analysis. HEK293 cells are well characterized cells, and their relevance as a model for toxicity assessment in humans is well established. ${ }^{6,7}$

Mesoporous silica, due to their large surface areas and easy permeability, has great potential as drug delivery vehicles and biosensors. One of the most commonly used mesoporous silica NPs, MCM-41, contains a hexagonal arrangement of adjustable pore channels. MCM-41 has been shown to exert concentration dependent toxicity on human $\mathrm{T}$ cell lymphoma and adenocarcinoma cells, but was not shown to elicit any toxicity or cell differentiation in mesenchymal stem cells. ${ }^{8-10}$ Nevertheless, some of the data on MCM-41 cell-based screens were found to be misleading due to the interference of MCM-41 itself with the 2,5-diphenyltetrazolium salt (MTT) used to asses toxicity. ${ }^{11,12}$ Iron oxide NPs 
$\left(\mathrm{Fe}_{2} \mathrm{O}_{3}\right.$ or $\left.\mathrm{Fe}_{3} \mathrm{O}_{4}\right)$ have been widely applied as magnetic drug targeting systems ${ }^{13,14}$ and contrast agents in magnetic imaging. Cell-based cytotoxicity studies have shown that human mesothelioma cells are sensitive to $\mathrm{Fe}_{2} \mathrm{O}_{3}-\mathrm{NPs}$ exposure, but rodent $3 \mathrm{~T} 3$ cells are non-responsive. ${ }^{15}$ In addition, when compared to other metal oxides, naked $\mathrm{Fe}_{2} \mathrm{O}_{3}$-NPs were found to have no inhibitory effects on human hematopoietic progenitor cell growth ${ }^{16}$ and did not induce any inflammatory response in human endothelial cells ${ }^{17}$ but caused marginal toxicity in lung epithelial cells. ${ }^{18}$ In view of the present literature, it is difficult to determine whether MCM41 and $\mathrm{Fe}_{2} \mathrm{O}_{3}$-NPs are free of associated toxicity, as most of the studies to date have not thoroughly investigated their effects on overall molecular changes occurring in cells.

$\mathrm{ZnO}$-NPs are one of the main constituents of sunscreens due to their UV filtering properties and are also used in the surface coatings of paints, plastics, and textiles to provide antibacterial and antifungal protection. In contrast to mesoporous silica and iron oxide NPs, the use of ZnO-NPs is raising concern as they have been shown to cause significant DNA damage and oxidative stress in a wide range of cell lines tested. ${ }^{19-21}$ Therefore, conducting a parallel analysis of cellular and molecular changes in cells exposed to biologically relevant concentrations of MCM-41 and $\mathrm{Fe}_{2} \mathrm{O}_{3}$ NPs in comparison to $\mathrm{ZnO}-\mathrm{NPs}$ will provide a better understanding of their toxicity.

\section{Materials and Methods}

Cell Culture and Nanoparticle Characterization. HEK293 cells were grown in Dulbecco's Modified Eagle's Medium (DMEM, Invitrogen, Carlsbad, CA, USA) containing 10\% fetal bovine serum (Invitrogen) and 1\% penicillin and streptomycin. MCM-41 and $\mathrm{Fe}_{2} \mathrm{O}_{3}$ - $\mathrm{NPs}$ were prepared as previously published ${ }^{19-21}$ and characterized as described in Supplementary Material. Surface morphology and synthesized sample size were examined by scanning electron microscopy (SEM, LEO 1455VP, Hitachi S-4700) at an acceleration voltage of $25 \mathrm{kV}$. Microscopic features of the samples were observed with a transmission electron microscope (TEM, EM 912 Omega) operated at $120 \mathrm{kV}$. Total pore volumes were determined from the amount of gas adsorbed at a relative pressure of 0.99 . Pore size distribution was derived from the adsorption branches by the BarrettJoyner-Halenda (BJH) method. Commercially prepared $\mathrm{ZnO}$ nanopowder, $\geq 100 \mathrm{~nm}$ in size, was obtained from Sigma Aldrich (St. Louis, MO, USA, Cat no: 544906). All the NPs were suspended in phosphate-buffered saline (PBS), sonicated, and immediately applied to HEK293 cells to minimize agglomeration. To further confirm the state of aggregation, NP test concentrations were prepared in DMEM containing $10 \% \mathrm{FCS}$ and incubated in culture dishes at $37^{\circ} \mathrm{C}$ under humidified conditions for $24 \mathrm{~h}$. Samples were then charged on grids and TEM images were acquired.

WST-1 Cell Viability Assay. HEK293 cells were seeded in 96-well cell culture plates at a density of $6 \times 10^{3}$ cells per well and incubated with $\mathrm{MCM}-41, \mathrm{Fe}_{2} \mathrm{O}_{3}$ and $\mathrm{ZnO}$ NPs at various concentrations in complete DMEM for 24,48 and $72 \mathrm{~h}$. For each concentration, six replicates were measured. Following incubation, $10 \mu \mathrm{L}$ of premixed WST-1 reagent (TaKaRa, Bio Inc., Shiga, Japan) were added to each well and further incubated for $2 \mathrm{~h}$. Color development was measured at $450 \mathrm{~nm}$ using an ELISA plate reader. All absorbance values were corrected against a blank, which was the same as the test wells except that it was devoid of cells. Percent cell viability was calculated considering the untreated control as $100 \%$ viable. The $\mathrm{IC}_{50}$ and $\mathrm{IC}_{20}$ values were calculated from dose response curves. Cytotoxic effect of nanoparticle-associated ions released in culture medium was also evaluated. Nanoparticles were resuspended in complete medium at indicated concentrations and were incubated for 24,48 and $72 \mathrm{~h}$, following which the NP suspensions were centrifuged at $13,000 \mathrm{rpm}$ for $10 \mathrm{~min}$ and the supernatant medium was collected. HEK293 cells were exposed to the so obtained conditioned medium for various timepoints viz $24 \mathrm{~h}$ in presence of $24 \mathrm{~h} \mathrm{NP}$-supernatent, $48 \mathrm{~h}$ in presence of $48 \mathrm{~h}$ NP-supernatent, $72 \mathrm{~h}$ in presence of $72 \mathrm{~h}$ NP-supernatent .

DNA Microarray. Cells were grown to $60 \%$ cell density and treated with $100 \mu \mathrm{g} / \mathrm{mL}$ MCM-41, $100 \mu \mathrm{g} / \mathrm{mL} \mathrm{Fe}_{2} \mathrm{O}_{3}$, and $12.5 \mu \mathrm{g} / \mathrm{mL} \mathrm{ZnO}$ in complete media for $24 \mathrm{~h}$. Total RNA was extracted using the TRI Reagent ${ }^{\mathbb{B}}$ kit (Ambion, Austin, TX, USA) according to manufacturer's instructions. Total RNA $(10 \mu \mathrm{g})$ was used for double-stranded cDNA (dscDNA) synthesis using a commercial kit (Invitrogen). Reactions were stopped with EDTA, treated with RNase A, and the dscDNA was ethanol-precipitated. One $\mu \mathrm{g}$ of dscDNA was used for labeling by Klenow fragments (New England Biolabs, Beverly, MA, USA) using a Cy3-labeled random 9mer (TriLink Biotechnologies, San Diego, CA, USA), and labeled samples were precipitated using isopropanol. Four $\mu \mathrm{g}$ of Cy3-labeled DNA (containing sample tracking control and alignment oligo) was hybridized to a NimbleGen 385K 4-plex human microarray for $18 \mathrm{~h}$ at $42^{\circ} \mathrm{C}$ using the NimbleGen Hybridization system (Roche NimbleGen Inc., Madison, WI, USA). Arrays were washed and images were obtained using an InnoScan ${ }^{\circledR} 900$ scanner (Innopsys, Carbonne, France). Scanned images were imported into Mapix software (Innopsys).

Microarray Data Analysis. Scanned images were imported into NimbleScan software. Expression data were normalized through quantile normalization and the Robust Multichip Average (RMA) algorithm. ${ }^{22}$ MA plots were generated in which the $\mathrm{X}$-axis represents the average $\log _{2}$ expression of the control and test samples and the Y-axis corresponds to the ratio of $\log _{2}$ expression value of the test to the control to visualize overall changes in gene expression. Fold change in expression for 24,000 genes was calculated for each NP relative to the non-treatment control. Transcripts with more than a 2-fold change in either direction were selected. Genes that were differentially expressed by the test materials were functionally categorized using a web-based program, Database for Annotation, Visualization and Integrated Discovery (DAVID) (http://david.abcc.ncifcrf.gov). ${ }^{23}$ 
Enrichment in gene ontology terms, for both up- and downregulated genes, was determined by Fisher exact $p<0.05$ and Count Threshold 2.

Quantitative Real-time PCR. RNA was extracted as described and $500 \mathrm{ng}$ was used as a template for cDNA synthesis, using the High Capacity cDNA Reverse Transcription kit (Applied Biosystems) according to the manufacturer's protocol. Aliquots of the cDNA reaction mixture were analyzed by quantitative real-time PCR using a StepOne real-time PCR thermocycler (Applied Biosystems). Primers used for target specific amplification are shown in Table S2. All primer pairs spanned an intron to avoid possible genomic DNA contamination. The PCR amplification cycle involved denaturation at $95^{\circ} \mathrm{C}$ for $15 \mathrm{~s}$, annealing at $60{ }^{\circ} \mathrm{C}$ for $20 \mathrm{~s}$, and extension at $72{ }^{\circ} \mathrm{C}$ for $15 \mathrm{~s}$. Quantitative real time PCR data for each gene product were normalized by GAPDH transcript levels and are reported as the mean $\pm \mathrm{SE}$ of relative change compared to the untreated control.

\section{Results and Discussion}

Particle Characterization. The MCM-41 particles were spherical in shape and approximately $110 \mathrm{~nm}$ in diameter, as shown in SEM and TEM images (Fig. S1). Each particle possessed mesoporous channels running throughout the particle with a pore size of $2.6 \mathrm{~nm}$ as indicated by the pore size distribution curve (Fig. S2). The $\mathrm{Fe}_{2} \mathrm{O}_{3}$ NPs synthesized in this work were demonstrated as hematite $\alpha-\mathrm{Fe}_{2} \mathrm{O}_{3}$ by XRD pattern as previously published..$^{21}$ The SEM image in Figure S1 clearly reveals that the product was composed of a large quantity of uniform hexagonal prism-like $\alpha-\mathrm{Fe}_{2} \mathrm{O}_{3}$. It was observed from the SEM and TEM images that the $\mathrm{Fe}_{2} \mathrm{O}_{3}$ sample exhibited a mainly hexagonal nanoplate form with an average parallel side, diagonal side, width, and thickness of $90-100 \mathrm{~nm}, 60-70 \mathrm{~nm}, 120-150 \mathrm{~nm}$, and $85-95 \mathrm{~nm}$, respectively. Commercially obtained $\mathrm{ZnO}$ nanopowder was $\geq 100 \mathrm{~nm}$ in size and had a surface area of $15-25 \mathrm{~m}^{2} / \mathrm{g}$. TEM images of NPs incubated in culture medium for $24 \mathrm{~h}$ suggest that no particle agglomeration was observed at $100 \mu \mathrm{g} / \mathrm{mL}$ of $\mathrm{MCM}-41$ and $\mathrm{Fe}_{2} \mathrm{O}_{3}$ and at $12.5 \mu \mathrm{g} / \mathrm{mL} \mathrm{ZnO}$ (Figure S3).

Nanoparticle Cytotoxicity on HEK293 Cells. HEK293 cells were exposed to increasing concentrations of test NP materials for 24,48 and $72 \mathrm{~h}$ and cell viability was then measured. All three NPs were earlier shown to be readily internalized into cultured mammalian cells. ${ }^{8,17}$ The WST-1 assay is the most sensitive assay available to measure the metabolic activities of viable cells and has the least background interference. Moreover, unlike MTT, WST-1 assay results are not affected by MCM-41-mediated changes in cellular trafficking. ${ }^{11}$ Dose response curves clearly show concentration dependent toxicity at all time points (Figure 1). Exposure duration did not significantly affect cell viability at lower MCM-41 and $\mathrm{ZnO}$ concentrations; however, at concentrations higher than the $\mathrm{IC}_{50}$ the extent of cytotoxicity seemed to correlate with the duration of exposure. $\mathrm{IC}_{50}$ values suggest that $\mathrm{MCM}-41$ and $\mathrm{Fe}_{2} \mathrm{O}_{3}$ had very similar toxicity profiles for 24 and $48 \mathrm{~h}$ of incubation. Unlike MCM-41 and $\mathrm{Fe}_{2} \mathrm{O}_{3}$, ZnO-NPs showed a remarkably steep relationship between $\mathrm{ZnO}$ concentration and cell death at concentrations ranging between $15-20 \mu \mathrm{g} / \mathrm{mL}$, leading to much higher $\mathrm{IC}_{50}$ values. A similar concentration dependent
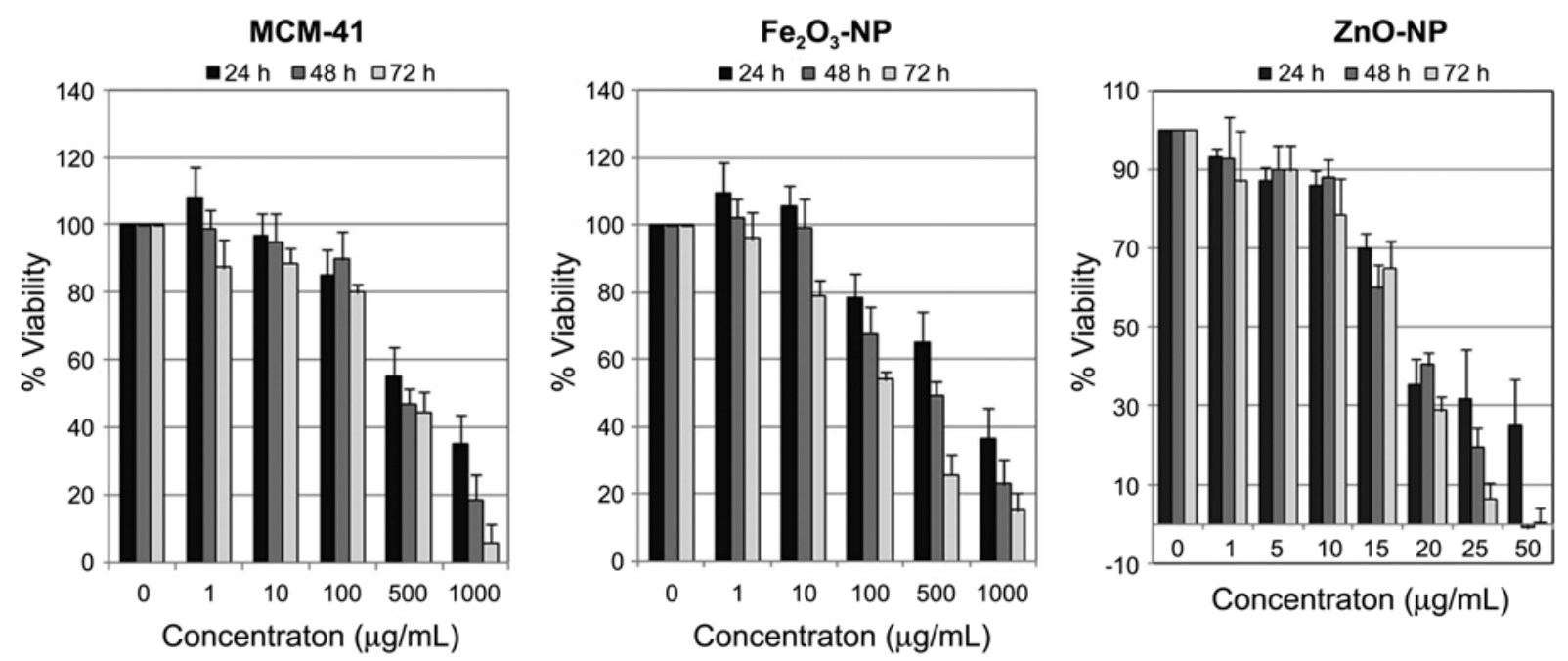

\begin{tabular}{|c|c|c|c|}
\hline $\begin{array}{c}\text { Duration of } \\
\text { incubation }\end{array}$ & $\begin{array}{c}\mathrm{MCM}-41 \\
(\mu \mathrm{g} / \mathrm{mL})\end{array}$ & $\begin{array}{c}\mathrm{Fe}_{2} \mathrm{O}_{3}-\mathrm{NP} \\
(\mu \mathrm{g} / \mathrm{mL})\end{array}$ & $\begin{array}{c}\mathrm{ZnO}-\mathrm{NP} \\
(\mu \mathrm{g} / \mathrm{mL})\end{array}$ \\
\hline $24 \mathrm{~h}$ & 574 & 698 & 21.47 \\
\hline $48 \mathrm{~h}$ & 461 & 464 & 20.19 \\
\hline $72 \mathrm{~h}$ & 423 & 116 & 16.58 \\
\hline
\end{tabular}

Figure 1. Effects of MCM-41, $\mathrm{Fe}_{2} \mathrm{O}_{3}$-NP, and $\mathrm{ZnO}-\mathrm{NP}$ on HEK293 cell viability. Cell viability after 24,48 and $72 \mathrm{~h}$ exposure to the test compounds was determined by WST-1 assays. The data are represented as the mean $\pm \mathrm{SE}$ of three independent experiments and is expressed as percent cell viability with respect to the untreated control as $100 \%$ viable. The $\mathrm{IC}_{50}$ values of these NPs are given in Table below. 
(a)

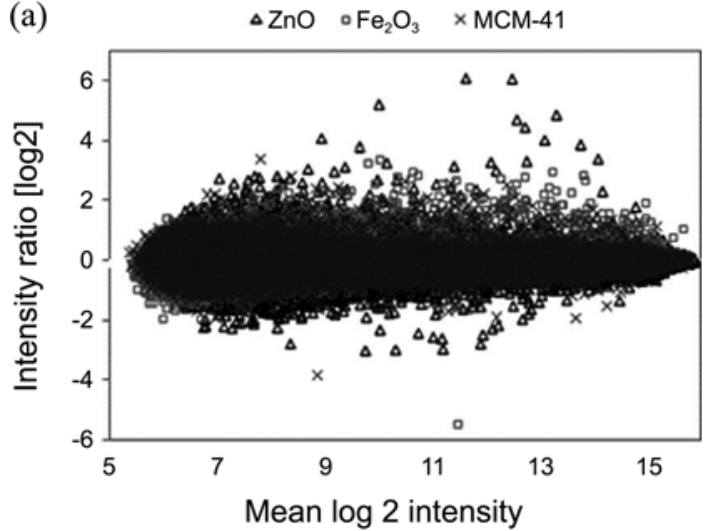

(b)

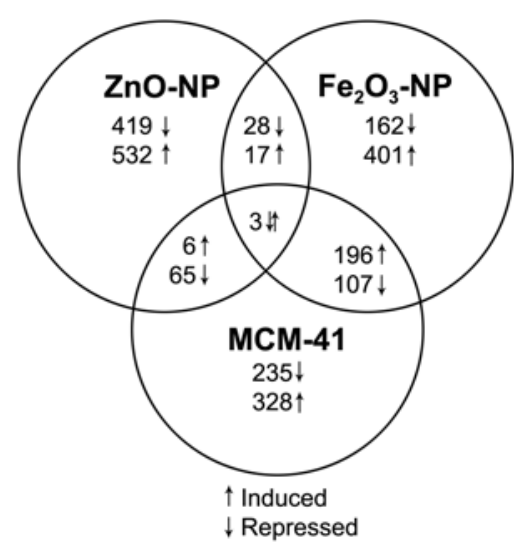

Figure 2. (a) MA Scatter plot showing overall distribution of gene expression upon NP exposure. (b) Venn diagrams illustrating genes induced or repressed by more than 2-fold upon nanoparticle exposure.

response towards $\mathrm{ZnO}-\mathrm{NPs}$ with a sudden drop in cell viability has been reported in the literature. ${ }^{19,24}$ Since metal oxide nanoparticles may be ionized during the sample preparation procedure and the subsequent ion leakage may result in a continuous formation of free radicals and metal ions, ${ }^{25,26}$ we also assessed the toxicity imparted due to nanoparticle associated ions. HEK293 cells incubated with NP-conditioned medium suggest that at higher concentrations all the three oxide-NPs resulted in toxicity due to the ions released in the culture medium (Figure S4). Although the contribution of metal ion associated toxicity in MCM41 and $\mathrm{Fe}_{2} \mathrm{O}_{3}$ seems to fairly low, exposure to $\mathrm{ZnO}$ conditioned medium for longer duration resulted in substantial toxicity. Nonetheless, NPs showed much higher cytotoxicity than ions released from NPs for all NPs tested. For further comparative assessment of these NPs, the cell viability assay data was considered as a basis for choosing their equipotent concentrations. Moreover, to make the study more relevant, concentrations were selected that resembled doses at which these NPs are used for human applications. An $\mathrm{IC}_{20}$ (concentrations that lead to $20 \%$ loss in viability) value for $24 \mathrm{~h}$ incubation was considered, as in all three cases, MCM-41 $(100 \mu \mathrm{g} / \mathrm{mL})^{27,28} \mathrm{Fe}_{2} \mathrm{O}_{3}(100 \mu \mathrm{g} / \mathrm{mL})^{29,30}$ and $\mathrm{ZnO}(12.5 \mu \mathrm{g} /$ $\mathrm{mL})^{31,32}$ the concentrations chosen were within the range used for biomedical or other applications.
Nanoparticle Mediated Gene Expression Changes in HEK293 Cells. We performed DNA microarray analysis of HEK293 cells exposed to $\mathrm{IC}_{20}$ concentrations of the selected NPs for $24 \mathrm{~h}$ to identify the molecular toxicity signature of the oxide NPs under study. The MA plots in Figure 2(a) (average intensity vs. intensity ratio) show the overall distributions of gene expression. The number of transcripts that had more than a 2-fold alteration in gene expression in either direction is shown in the Venn diagram (Figure 2(b)). As can be seen, the number and magnitude of genes that were induced were greater in number than those that were repressed. Even at similar cytotoxic concentrations, $\mathrm{ZnO}-$ NPs induced greater alterations in gene expression (both number and magnitude) in comparison to the other two test materials. Genes with altered expression and associations with cellular toxicity are listed in Table S1. The genes with altered expression were functionally annotated and the gene ontology (GO) terms with their respective fold-enrichment values were determined (Figure 3(a) and (b)).

Both $\mathrm{Fe}_{2} \mathrm{O}_{3}$ and MCM-41 induced expressions of many genes that encode for $40 \mathrm{~S}$ and $60 \mathrm{~S}$ ribosomal protein homologs. These two NPs also resulted in increased expression of various genes that encode for histones (histone 1, h2ad, h2a, h3 family b) involved in chromatin remodeling. CCL15, a cytokine involved in inflammation and chemotaxis $^{33}$ was up-regulated by both MCM-41 and $\mathrm{Fe}_{2} \mathrm{O}_{3}$. Further gene ontology analysis clearly showed that $\mathrm{Fe}_{2} \mathrm{O}_{3}$ induced more significant changes than MCM-41. Three genes that are associated with the JNK signaling pathway were up regulated upon $\mathrm{Fe}_{2} \mathrm{O}_{3}$ exposure (Table S1). JNK signaling is mainly involved in the maintenance of cell viability and proliferation in response to environmental fluctuations and stress. ${ }^{34}$ In addition, genes involved in renal system processes, neuron development, and cell proliferation (natriuretic peptide precursor $b$, endothelin1 and 2, bone morphogenic protein, fibroblast growth factor 8) were also down regulated by $\mathrm{Fe}_{2} \mathrm{O}_{3}$ but not by MCM-41. Defense response and stress associated genes pregnancy specific beta1 glycoproteins (PSG1 and PSG2) ${ }^{35}$ were significantly induced by $\mathrm{Fe}_{2} \mathrm{O}_{3}$ while only PSG1 was induced by MCM41.

Unlike MCM-41 and $\mathrm{Fe}_{2} \mathrm{O}_{3}$ NPs, $\mathrm{ZnO}$-NP resulted in the altered expression of many genes involved in cell death and apoptosis, indicating that even at low concentrations $\mathrm{ZnO}$ generates significant toxic responses in the cell. The induced genes included tumor necrosis factor ligands and receptors, interleukin1 beta, interleukin24, von hippel-lindau, somatostatin receptor2, phosphodiesterase7, matrix metalloprotease-9, growth arrest and DNA damage inducible alpha and gamma oncostatin $\mathrm{m}$, protein kinase $\mathrm{C}$ gamma, fas apoptotic inhibitory molecule 3 , inhibin beta a, and bcl 2 like protein. In addition, many genes of the metallothionein family namely MT2a, MT1X, MT1g, MT1b, MT1f showed more than 10-fold induction upon $\mathrm{ZnO}-\mathrm{NP}$ exposure. Metallothioneins are a family of cysteine rich metal binding proteins that are involved in metal detoxification and in the protection of cells against reactive oxygen species (ROS). In an earlier study, 
(a)

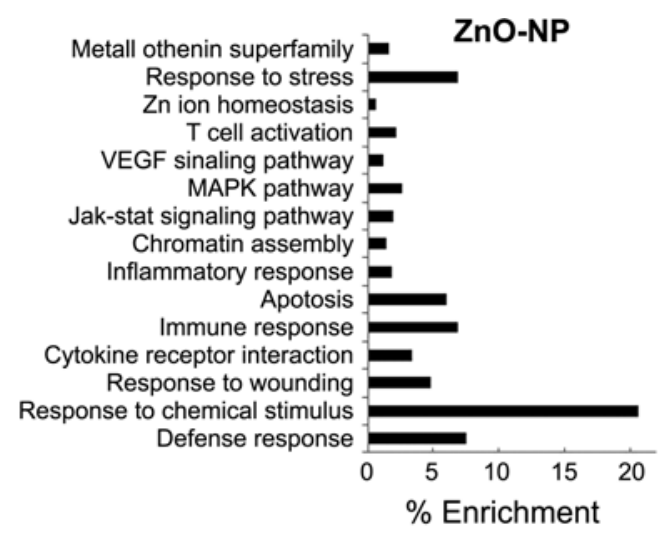

(b)

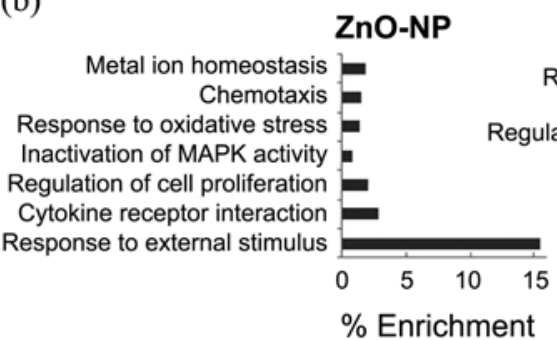

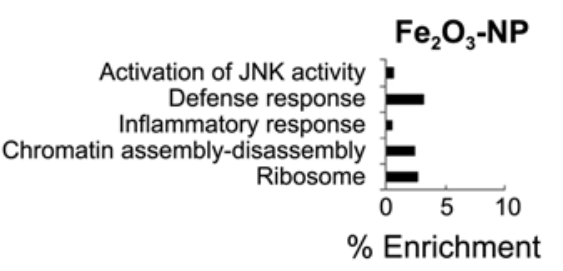

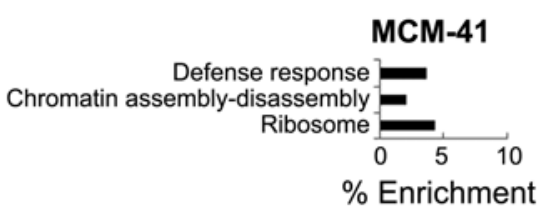

MCM-41

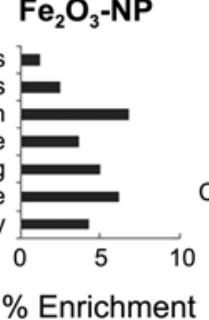

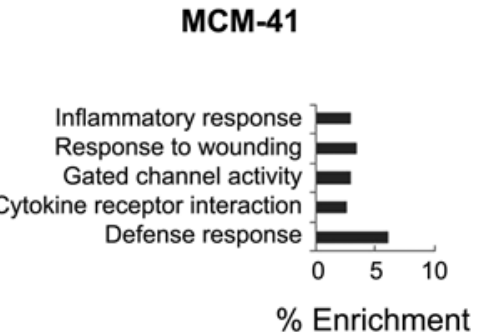

Figure 3. Categorization of greater than 2-fold altered genes on the basis of their gene ontology. (a) up-regulated (b) and down-regulated. Each bar represents the percent enrichment of the GO term against total altered genes as background.

silver NPs were shown to induce the expression of metallothionein genes in liver cells. ${ }^{36}$ Most of the studies conducted with $\mathrm{ZnO}-\mathrm{NPs}$ suggest that $\mathrm{ZnO}$-mediated toxicity is primarily a result of oxidative stress and the generation of ROS. ${ }^{19}$ In our study, in addition to the up-regulation of metallothioneins, we also observed reductions in eosinophil peroxidase and superoxide dismutase 2 mitochondrial (MnSOD) levels. Superoxide dismutase converts superoxide anion to hydrogen peroxide. In renal diseases, polycystic kidney damage oxidative stress and synthesis of $\mathrm{H}_{2} \mathrm{O}_{2}$ results in reduced mRNA levels of important antioxidant enzymes including MnSOD. ${ }^{37}$ Reduction of mitochondrial SOD in our study suggests that upon prolonged exposure to $\mathrm{ZnO} \mathrm{NPs}$, the antioxidant activities of cells were compromised, which would further potentiate its toxicity. The findings of our study are also in agreement with earlier reports on $\mathrm{ZnO}-\mathrm{NPs}$ in which similar changes in SOD expression and eosinophil peroxide transcription were observed. ${ }^{17,19} \mathrm{We}$ also observed induction of genes involved in $\mathrm{Ca}^{2+}$ homeostasis, namely protein kinase $\mathrm{C}$ gamma, $\mathrm{S} 100$ calcium binding protein, calbindin2, to name a few (Table S1). Some signaling pathways were also up regulated in ZnO-NPs treated samples, namely MAPK, Jak-Stat and VEGF signaling pathways.

Real Time PCR Validation of Key Toxicity Associated Genes. Based on the microarray expression changes and Gene Ontology search, eight genes that were up-regulated and associated with cellular toxicity were validated by realtime PCR. Among these, four genes, heat shock protein 6 (HSPA6), matrix metalloprotease 1 (MMP1), and pregnancy specific beta1 glycoprotein (PSG1, PSG9), showed more than 1.5 -fold induction by all three NPs in the microarray analysis. Of the remaining four genes, chemokine $\mathrm{C}-\mathrm{C}$ motif receptor 15 (CCL15) showed $\mathrm{Fe}_{2} \mathrm{O}_{3}$ and MCM-41 specific up-regulation, while v-fos fbj murine osteosarcoma viral oncogene homolog ( $\mathrm{vFOS}$ fbj) was strongly induced by $\mathrm{ZnO}$ and to a lesser extent by $\mathrm{Fe}_{2} \mathrm{O}_{3}$. The interleukin17f (IL17f) and metallothionein $2 \mathrm{a}$ genes were specifically induced by $\mathrm{ZnO}$. The fold changes in expressions of these genes obtained from microarray analysis are provided in Table S1. For all genes tested, the general dose response trends observed with real time PCR were consistent with microarray analyses (Fig. 4). However, in some cases the magnitude of fold induction seen in real-time PCR was higher than measured by microarray analysis, which was expected, as the dynamic range afforded by microarray is comparatively much lower. Only in the case of HSPA6 did we find that the microarray results were much higher than the actual changes in gene expression. Altogether, the results of real time PCR validation were in agreement with the microarray data, suggesting that the all three test materials induced expression of toxicityassociated genes. However, in comparison to $\mathrm{Fe}_{2} \mathrm{O}_{3}$ and $\mathrm{MCM}-41, \mathrm{ZnO}$ exposure showed greater changes in expression, both in number and magnitude.

In conclusion, the data clearly show that although these three oxide NPs cause toxicity in cells, ZnO-NPs-mediated toxicity is much higher than those of MCM- 41 and $\mathrm{Fe}_{2} \mathrm{O}_{3}$. Levels of cytotoxic response were observed in the following order: MCM-41 $<\mathrm{Fe}_{2} \mathrm{O}_{3}$-NPs $<$ ZnO-NP. Gene ontology enrichment suggests that MCM-41 and $\mathrm{Fe}_{2} \mathrm{O}_{3}$ exposure, even at the concentrations used for various biomedical applications lead to toxic phenotypes in cells which can be classified as early response of cells towards environmental stressor. Although MCM-41 appeared to have marginal toxi- 

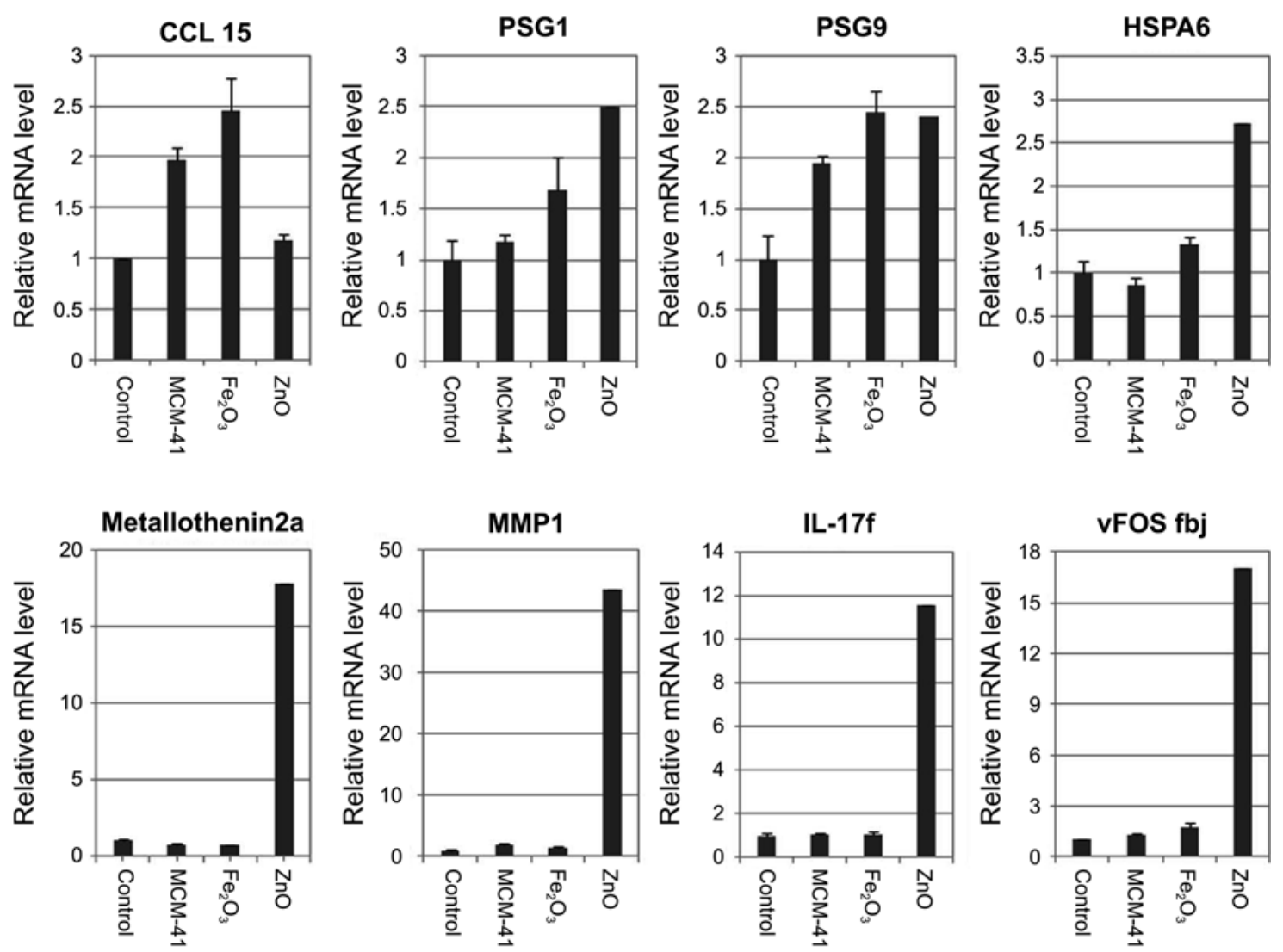

Figure 4. Real time PCR validation of selected genes that were found to be induced by NP exposure and have associations with toxic responses in the cells.

city, $\mathrm{Fe}_{2} \mathrm{O}_{3}$-NP-mediated alteration in gene expression implies toxicity above threshold levels, which the cell may or may not overcome depending upon the duration of exposure and the cell type. $\mathrm{ZnO}$, even at lower concentrations, can induce substantial toxic responses in cells that are sufficient to trigger programmed cell death; hence, the use of $\mathrm{ZnO}$ for human applications should be scrutinized to establish safe levels prior to use. Therefore, our study shows that these NPs are more biologically challenging than originally thought. Further studies are needed to understand shape/size dependent cellular effects and the effects of surface modifications in overcoming these toxicity issues in order to provide a safe window for their end use.

Acknowledgments. This work was supported by a grant from the Ministry of Environment Eco-Technopia 21 Project (091-081-073) to D.-k. Lee. P.D. acknowledges support from the Sungkyunkwan University Post-Doctoral Fellowship in 2008 .

\section{References}

1. Rothen-Rutishauser, B. M.; Schurch, S.; Haenni, B.; Kapp, N.; Gehr, P. Environ. Sci. Technol. 2006, 40, 4353-4359.

2. Huang, X.; Teng, X.; Chen, D.; Tang, F.; He, J. Biomaterials 2010 , $31,438-448$.

3. Tang, J.; Xiong, L.; Wang, S.; Wang, J.; Liu, L.; Li, J.; Yuan, F.; Xi, T. J. Nanosci. Nanotechnol. 2009, 9, 4924-4932.
4. Oberdorster, G.; Elder, A.; Rinderknecht, A. J. Nanosci. Nanotechnol. 2009, 9, 4996-5007.

5. Long, T. C.; Saleh, N.; Tilton, R. D.; Lowry, G. V.; Veronesi, B. Environ. Sci. Technol. 2006, 40, 4346-4352.

6. Ji, L. L.; Chen, Y.; Wang, Z. T. Exp. Toxicol. Pathol. 2008, 60, $87-$ 93.

7. Florea, A. M.; Splettstoesser, F.; Busselberg, D. Toxicol. Appl. Pharmacol. 2007, 220, 292-301.

8. Tao, Z.; Toms, B. B.; Goodisman, J.; Asefa, T. Chem. Res. Toxicol. 2009, 22, 1869-1880.

9. Di Pasqua, A. J.; Sharma, K. K.; Shi, Y. L.; Toms, B. B.; Ouellette, W.; Dabrowiak, J. C.; Asefa, T. J. Inorg. Biochem. 2008, 102, 1416-1423.

10. Huang, D. M.; Chung, T. H.; Hung, Y.; Lu, F.; Wu, S. H.; Mou, C. Y.; Yao, M.; Chen, Y. C. Toxicol. Appl. Pharmacol. 2008, 231, 208-215.

11. Fisichella, M.; Dabboue, H.; Bhattacharyya, S.; Saboungi, M. L.; Salvetat, J. P.; Hevor, T.; Guerin, M. Toxicol. In Vitro 2009, 23, 697-703.

12. Laaksonen, T.; Santos, H.; Vihola, H.; Salonen, J.; Riikonen, J.; Heikkila, T.; Peltonen, L.; Kumar, N.; Murzin, D. Y.; Lehto, V. P.; Hirvonen, J. Chem. Res. Toxicol. 2007, 20, 1913-1918.

13. Alexiou, C.; Jurgons, R.; Schmid, R.; Erhardt, W.; Parak, F.; Bergemann, C.; Iro, H. Hno. 2005, 53, 618-622.

14. Berry, C. C.; Wells, S.; Charles, S.; Curtis, A. S. Biomaterials 2003, 24, 4551-4557.

15. Brunner, T. J.; Wick, P.; Manser, P.; Spohn, P.; Grass, R. N.; Limbach, L. K.; Bruinink, A.; Stark, W. J. Environ. Sci. Technol. 2006, 40, 4374-4381.

16. Bregoli, L.; Chiarini, F.; Gambarelli, A.; Sighinolfi, G.; Gatti, A. M.; Santi, P.; Martelli, A. M.; Cocco, L. Toxicology 2009, 262, 121-129. 
17. Kennedy, I. M.; Wilson, D.; Barakat, A. I. Res. Rep. Health Eff. Inst. 2009, 3-32.

18. Karlsson, H. L.; Cronholm, P.; Gustafsson, J.; Moller, L. Chem. Res. Toxicol. 2008, 21, 1726-1732.

19. Huang, C. C.; Aronstam, R. S.; Chen, D. R.; Huang, Y. W. Toxicol. In Vitro 2009.

20. Deng, X.; Luan, Q.; Chen, W.; Wang, Y.; Wu, M.; Zhang, H.; Jiao, Z. Nanotechnology 2009, 20, 115101.

21. Sharma, V.; Shukla, R. K.; Saxena, N.; Parmar, D.; Das, M.; Dhawan, A. Toxicol. Lett 2009, 185, 211-218.

22. Hong, S. W.; Hong, S. M.; Yoo, J. W.; Lee, Y. C.; Kim, S.; Lis, J. T.; Lee, D. K. Proc. Natl. Acad Sci. USA 2009, 106, 14276-14280.

23. Dennis, G., Jr.; Sherman, B. T.; Hosack, D. A.; Yang, J.; Gao, W.; Lane, H. C.; Lempicki, R. A. Genome. Biol. 2003, 4, P3.

24. Gojova, A.; Guo, B.; Kota, R. S.; Rutledge, J. C.; Kennedy, I. M.; Barakat, A. I. Environ. Health Perspect. 2007, 115, 403-409.

25. Cho, W. S.; Duffin, R.; Poland, C. A.; Duschl, A.; Oostingh, G. J.; Macnee, W.; Bradley, M.; Megson, I. L.; Donaldson, K. Nanotoxicology 2011.

26. Baek, Y. W.; An, Y. J. Sci. Total Environ. 2011, 409, 1603-1608.

27. Radu, D. R.; Lai, C. Y.; Jeftinija, K.; Rowe, E. W.; Jeftinija, S.; Lin, V. S. J. Am. Chem. Soc. 2004, 126, 13216-13217.

28. Slowing, II.; Vivero-Escoto, J. L.; Wu, C. W.; Lin, V. S. Adv.
Drug. Deliv. Rev. 2008, 60, 1278-1288.

29. Smirnov, P.; Lavergne, E.; Gazeau, F.; Lewin, M.; Boissonnas, A.; Doan, B. T.; Gillet, B.; Combadiere, C.; Combadiere, B.; Clement, O. Magn. Reson. Med. 2006, 56, 498-508.

30. Smirnov, P.; Gazeau, F.; Lewin, M.; Bacri, J. C.; Siauve, N.; Vayssettes, C.; Cuenod, C. A.; Clement, O. Magn. Reson. Med. 2004, 52, 73-79.

31. Cross, S. E.; Innes, B.; Roberts, M. S.; Tsuzuki, T.; Robertson, T. A.; McCormick, P. Skin Pharmacol. Physiol. 2007, 20, 148-154.

32. Nohynek, G. J.; Lademann, J.; Ribaud, C.; Roberts, M. S. Crit Rev. Toxicol. 2007, 37, 251-277.

33. Pardigol, A.; Forssmann, U.; Zucht, H. D.; Loetscher, P.; SchulzKnappe, P.; Baggiolini, M.; Forssmann, W. G.; Magert, H. J. Proc. Natl. Acad Sci. U S A 1998, 95, 6308-6313.

34. Nishina, H. W. T.; Katada, T. J. Biochem. 2004, 136, 123-126.

35. Snyder, S. K.; Wessner, D. H.; Wessells, J. L.; Waterhouse, R. M.; Wahl, L. M.; Zimmermann, W.; Dveksler, G. S. Am. J. Reprod. Immunol. 2001, 45, 205-216.

36. Kawata, K.; Osawa, M.; Okabe, S. Environ. Sci. Technol. 2009, 43, 6046-6051.

37. Maser, R. L.; Vassmer, D.; Magenheimer, B. S.; Calvet, J. P. J. Am. Soc. Nephrol. 2002, 13, 991-999. 


\title{
Supporting Information
}

\section{Evaluation of Toxicity and Gene Expression Changes Triggered by Oxide Nanoparticles}

\author{
Pooja Dua, ${ }^{\dagger, \star, a}$ Kiran N. Chaudhari, ${ }^{\S, a}$ Chang Han Lee, ${ }^{\dagger}$ Nitin K. Chaudhari, \\ Sun Woo Hong, ${ }^{\dagger}$ Jong-Sung Yu, ${ }^{\S, *}$ Soyoun Kim, $,{ }^{\ddagger}, "$ and Dong-ki Lee ${ }^{\dagger, *}$
}

${ }^{\dagger}$ Global Research Laboratory for RNAi Medicine, Department of Chemistry and BK21 School of Chemical Materials Science, Sungkyunkwan University, Suwon 440-746, Korea. "E-mail: dklee@skku.edu (D.-k. Lee)

${ }^{\ddagger}$ Department of Biomedical Engineering, Dongguk University, Seoul 100-715, Korea. *E-mail: skim@dongguk.edu (S. Kim)

${ }^{\S}$ Department of Advanced Materials Chemistry, BK21 Research Team, Korea University, Chungnam 339-700, Korea

*E-mail: jsyu212@korea.ac.kr (J.S.Yu)

Received January 10, 2011, Accepted April 25, 2011
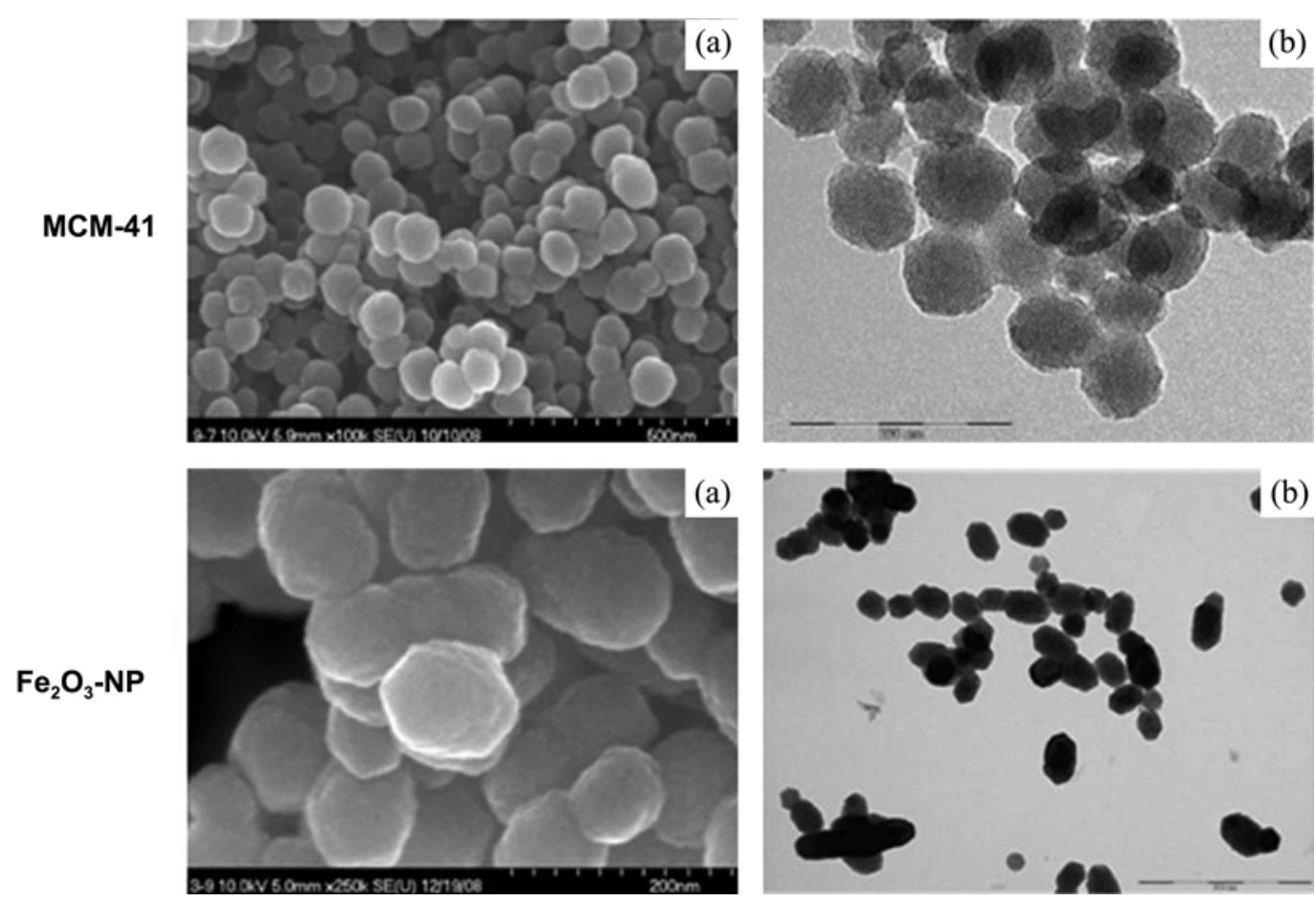

Figure S1. Scanning electron microscopic image (a) and Transmission electron microscopy image (b) of $\mathrm{MCM}^{-41}$ (up) and $\mathrm{Fe}_{2} \mathrm{O}_{3}$ nanoparticles (down). 


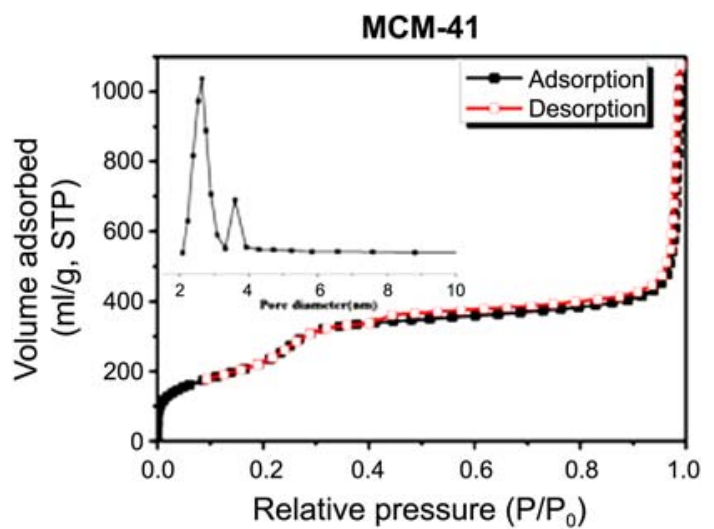

$\mathrm{Fe}_{2} \mathrm{O}_{3}-\mathrm{NP}$

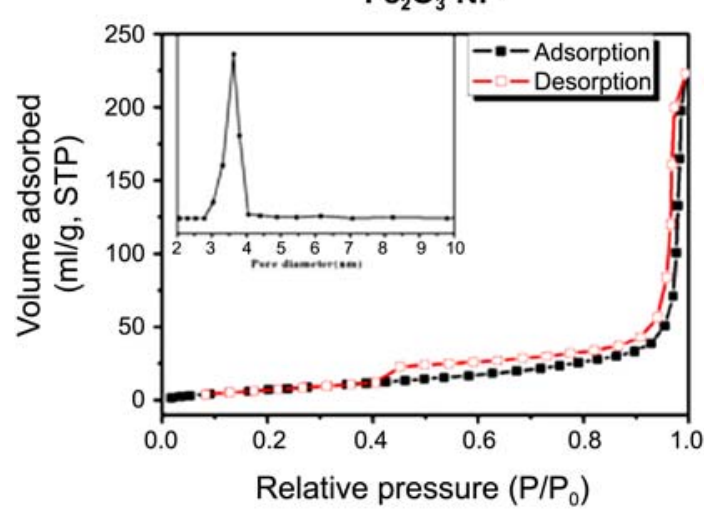

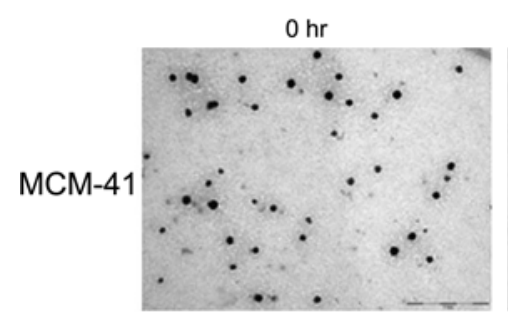
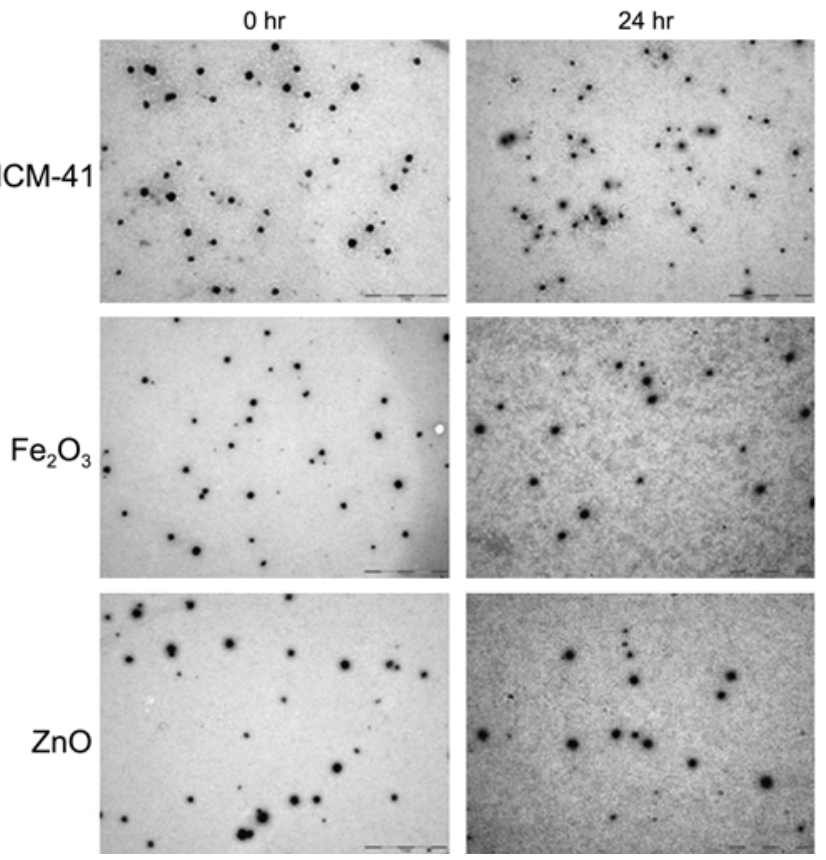

Figure S3. TEM images of nanoparticles show absence of any agglomeration in culture conditions. Test concentrations of nanparticles i.e. $100 \mu \mathrm{g} / \mathrm{mL}$ of MCM-41, $100 \mu \mathrm{g} / \mathrm{mL}$ of $\mathrm{Fe}_{2} \mathrm{O}_{3}$ and $12.5 \mu \mathrm{g} / \mathrm{mL}$ of $\mathrm{ZnO}$ were incubated for $24 \mathrm{~h}$ in complete medium. TEM images of NPs in culture medium with and without incubation were acquired. The scale bar measures $1 \mu \mathrm{m}$.

Figure S2. N2 adsorption/desorption isotherms for surface area measurement and pore size distribution (the inset) of MCM-4land $\mathrm{Fe}_{2} \mathrm{O}_{3}$ nanoparticles. Pore size distribution is given as the inset.
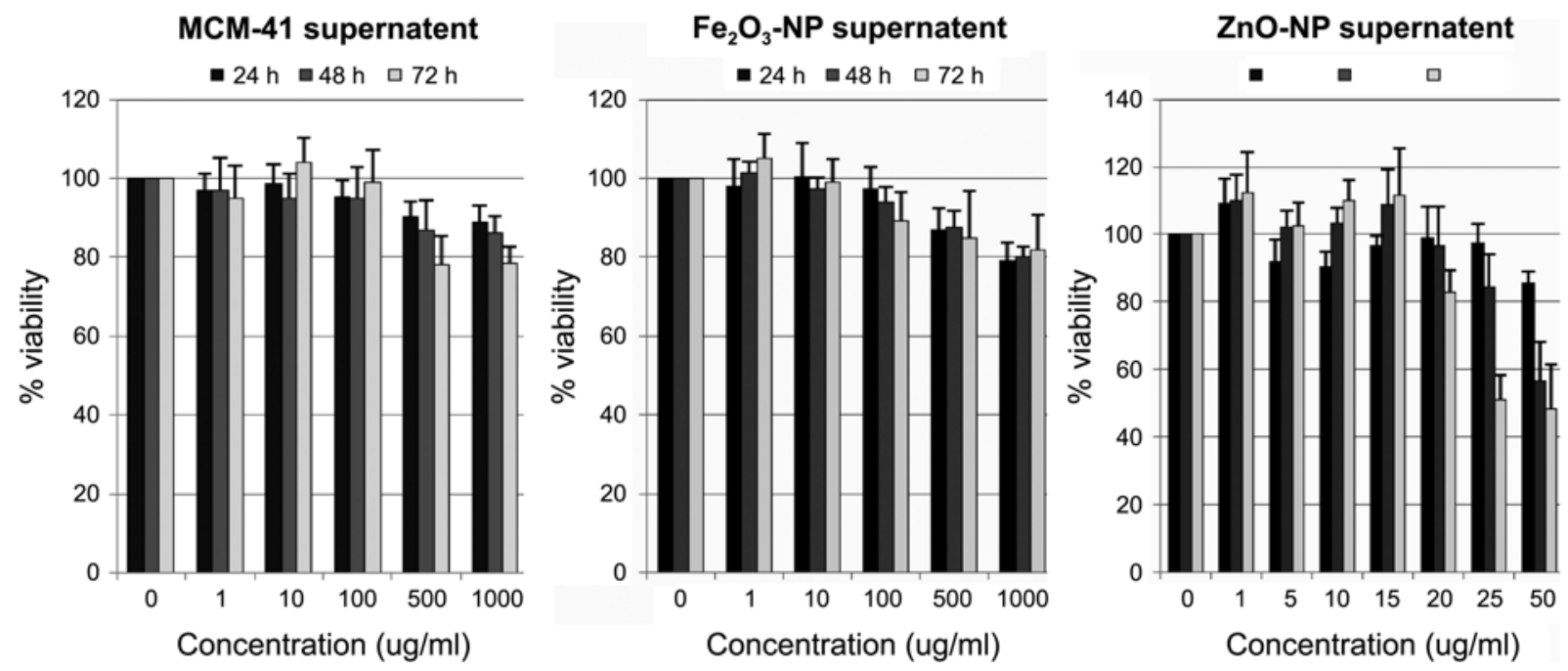

Figure S4. Cytotoxic effect of nanoparticle-associated ions released in culture medium. HEK293 cells were exposed to the NPsupernatant culture medium for the indicated time-points viz $24 \mathrm{~h}$ in presence of $24 \mathrm{~h} \mathrm{NP}$-supernatant, $48 \mathrm{~h}$ in presence of $48 \mathrm{~h}$ NPsupernatent, $72 \mathrm{~h}$ in presence of $72 \mathrm{~h} \mathrm{NP-supernatant.} \mathrm{The} \mathrm{toxicity} \mathrm{was} \mathrm{evaluated} \mathrm{by} \mathrm{WST-1} \mathrm{reagent.}$ 
Table S1. List of genes and associated biological processes altered by nanoparticles exposure I MCM-41 regulated genes ( $>2$ fold)

\begin{tabular}{|c|c|c|c|}
\hline Gene ID & Gene Name & Intens & Enriched Gene Ontology Term \\
\hline NM_001039664 & tumor necrosis factor receptor superfamily, member 25 & 0.46 & chemokine-chemokine receptor interaction \\
\hline NM_001005611 & ectodysplasin a & 0.47 & chemokine-chemokine receptor interaction \\
\hline XM_370909 & similar to h2a histone family, member $\mathrm{v}$ isoform 2 & 3.32 & chromatin assembly-disassembly \\
\hline NM_021065 & histone 1, h2ad & 2.44 & chromatin assembly-disassembly \\
\hline XM_293312 & similar to h3 histone, family $3 \mathrm{~b}$ & 2.52 & chromatin assembly-disassembly \\
\hline NM_172220 & colony stimulating factor 3 (granulocyte) & 2.11 & defense \\
\hline NM_182707 & pregnancy specific beta-1-glycoprotein 3 & 2.11 & defense \\
\hline NM_172313 & colony stimulating factor 3 receptor (granulocyte) & 2.16 & defense \\
\hline NM_014707 & histone deacetylase 9 & 2.04 & defense \\
\hline NM_002784 & pregnancy specific beta-1-glycoprotein 9 & 2.19 & defense \\
\hline NM_003525 & histone $1, \mathrm{~h} 2 \mathrm{bd}$ & 2.35 & defense \\
\hline NM_153325 & defensin, beta 125 & 2.52 & defense \\
\hline NM_003264 & toll-like receptor 2 & 2.22 & defense \\
\hline NM_001030288 & sialophorin (gpl115, leukosialin, cd43) & 2.45 & defense \\
\hline NM_172175 & interleukin 15 & 0.45 & defense \\
\hline NM_025258 & chromosome 6 open reading frame 27 & 0.4 & defense \\
\hline NM_005449 & fas apoptotic inhibitory molecule 3 & 0.45 & defense \\
\hline NM_138938 & regenerating islet-derived 3 alpha & 0.41 & defense \\
\hline NM_000760 & colony stimulating factor 3 receptor (granulocyte) & 0.4 & defense \\
\hline NM_152251 & defensin, beta $106 \mathrm{a}$ & 0.46 & defense \\
\hline NM_004977 & $\begin{array}{l}\text { potassium voltage-gated channel, shaw-related subfamily, } \\
\text { member } 3\end{array}$ & 0.49 & gated channel activity \\
\hline NM_021196 & solute carrier family 4, , member 5 & 0.44 & gated channel activity \\
\hline NM_133497 & potassium channel, subfamily v, member 2 & 0.49 & gated channel activity \\
\hline NM_001014797 & potassium large conductance calcium-activated channel & 0.47 & gated channel activity \\
\hline NM_000121 & erythropoietin receptor & 0.47 & gated channel activity \\
\hline NM_005628 & Chemokine $\mathrm{C}$-c motif ligand 8 & 0.44 & Inflammation, \\
\hline NM_000892 & kallikrein b, plasma (fletcher factor) 1 & 0.35 & Inflammation, response to wounding \\
\hline NM_174872 & purinergic receptor $\mathrm{p} 2 \mathrm{x}$ & 0.45 & Ion transport \\
\hline NM_018979 & kinase deficient protein & 0.47 & Ion transport \\
\hline NM_001858 & collagen, type xix, alpha 1 & 0.49 & Ion transport \\
\hline NM_002978 & sodium channel, nonvoltage-gated 1 , delta & 0.44 & Ion transport \\
\hline NM_005416 & small proline-rich protein 3 & 0.48 & response to wounding \\
\hline NM_002965 & s100 calcium binding protein a9 (calgranulin b) & 0.47 & response to wounding \\
\hline NM_001572 & interferon regulatory factor 7 & 0.49 & response to wounding \\
\hline XM_496362 & $\begin{array}{l}\text { similar to } 60 \text { s ribosomal protein } 16 \text { (tax-responsive enhancer } \\
\text { element binding protein 107) }\end{array}$ & 2.57 & ribosomal processes \\
\hline XM_171158 & similar to ribosomal protein s2; 40s ribosomal protein s2 & 2.2 & ribosomal processes \\
\hline XM_376787 & ribosomal protein s 26 pseudogene 10 & 2.62 & ribosomal processes \\
\hline XM_497590 & similar to 60 s ribosomal protein $129(\mathrm{p} 23)$ & 2.34 & ribosomal processes \\
\hline XM_372759 & $\begin{array}{l}\text { similar to } 60 \text { s ribosomal protein } 110 \text { (qm protein) (tumor } \\
\text { suppressor qm) (laminin receptor homolog) }\end{array}$ & 2.14 & ribosomal processes \\
\hline XM_928025 & $\begin{array}{l}\text { similar to } 60 \text { s ribosomal protein } 110 \text { (qm protein) (tumor } \\
\text { suppressor qm) (laminin receptor homolog) }\end{array}$ & 3.01 & ribosomal processes \\
\hline XM_496363 & similar to ribosomal protein s2 & 2.98 & ribosomal processes \\
\hline XM_373343 & similar to 60 s ribosomal protein 132 & 3.01 & ribosomal processes \\
\hline XM_927179 & similar to 40 s ribosomal protein s 26 & 2.47 & ribosomal processes \\
\hline XM_497357 & similar to ribosomal protein 110 & 4.7 & ribosomal processes \\
\hline XM_069734 & similar to ribosomal protein 118 & 2.87 & ribosomal processes \\
\hline XM_060417 & similar to ribosomal protein 136 & 2.46 & ribosomal processes \\
\hline XM_497657 & similar to 40 s ribosomal protein s 16 & 2.3 & ribosomal processes \\
\hline XM_925952 & similar to 40 s ribosomal protein s 17 & 2.12 & ribosomal processes \\
\hline
\end{tabular}


II $\mathrm{Fe}_{2} \mathrm{O}_{3}-\mathrm{NP}$ regulated genes ( $>2$ fold)

\begin{tabular}{|c|c|c|c|}
\hline Gene ID & Gene Name & Intens & Enriched Gene Ontology Term \\
\hline NM_005314 & gastrin-releasing peptide receptor & 0.35 & cell proliferation \\
\hline NM_004449 & v-ets erythroblastosis virus e 26 oncogene like (avian) & 0.36 & cell proliferation \\
\hline NM_138279 & bcl2/adenovirus e1b 19kd interacting protein like & 0.42 & cell proliferation \\
\hline NM_002909 & $\begin{array}{l}\text { regenerating islet-derived } 1 \text { alpha (pancreatic stone } \\
\text { protein) }\end{array}$ & 0.42 & cell proliferation \\
\hline NM_002315 & $\lim$ domain only 1 (rhombotin 1$)$ & 0.44 & cell proliferation \\
\hline NM_080718 & t-box 5 & 0.47 & cell proliferation \\
\hline NM_014482 & bone morphogenetic protein 10 & 0.48 & cell proliferation \\
\hline NM_033163 & fibroblast growth factor 8 (androgen-induced) & 0.49 & cell proliferation \\
\hline NM_004946 & dedicator of cytokinesis 2 & 0.26 & chemotaxis \\
\hline NM_181287 & cklf-like marvel transmembrane domain containing 1 & 0.40 & chemotaxis \\
\hline NM_003539 & h4 histone, family 2 & 2.24 & chromatin assembly- disassembly \\
\hline NM_003513 & histone $1, \mathrm{~h} 2 \mathrm{ae}$ & 2.29 & chromatin assembly -disassembly \\
\hline NM_003510 & histone 1, h2ai & 2.32 & chromatin assembly -disassembly \\
\hline XM_371701 & similar to set protein (i-2pp2a) (taf-i) (phapii) (igaad) & 2.46 & chromatin assembly -disassembly \\
\hline XM_370909 & similar to h2a histone family, member $\mathrm{v}$ isoform 2 & 2.50 & chromatin assembly -disassembly \\
\hline XM_926257 & similar to set protein (i-2pp2a) (taf-i) & 2.54 & chromatin assembly- disassembly \\
\hline NM_021065 & histone 1, h2ad & 2.58 & chromatin assembly -disassembly \\
\hline NM_003493 & histone $3, \mathrm{~h} 3$ & 2.71 & chromatin assembly -disassembly \\
\hline NM_003523, & histone $1, \mathrm{~h} 2 \mathrm{bd}$ & 2.77 & chromatin assembly -disassembly \\
\hline XM_293312 & similar to h3 histone, family $3 \mathrm{~b}$ & 3.31 & chromatin assembly -disassembly \\
\hline NM_001037731 & defensin, beta 116 & 0.48 & defense \\
\hline NM_058201 & sperm associated antigen 11 & 0.49 & defense \\
\hline NM_002127 & hla-g histocompatibility antigen, class $\mathrm{i}, \mathrm{g}$ & 2.02 & defense \\
\hline NM_002255 & killer cell immunoglobulin-like receptor & 2.34 & defense \\
\hline NM_007053 & cd160 antigen & 2.97 & defense \\
\hline NM_002173 & interferon, alpha 16 & 0.45 & $\begin{array}{l}\text { defense, chemokine-chemokine receptor interaction, } \\
\text { inflammatory response }\end{array}$ \\
\hline NM_002704 & $\begin{array}{l}\text { pro-platelet basic protein (chemokine (c-X-c motif) } \\
\text { ligand 7) }\end{array}$ & 0.49 & $\begin{array}{l}\text { defense, chemokine-chemokine receptor interaction, } \\
\text { inflammatory response, cell proliferation, } \\
\text { chemotaxis }\end{array}$ \\
\hline NM_001030288 & sialophorin (gpl115, leukosialin, cd43) & 2.15 & defense, inflammatory response \\
\hline NM_005623 & chemokine (c-c motif) ligand 8 & 0.42 & $\begin{array}{l}\text { defense, response to wounding, chemokine - } \\
\text { chemokine receptor interaction, inflammatory } \\
\text { response, chemotaxis }\end{array}$ \\
\hline NM_002965 & s100 calcium binding protein a9 (calgranulin b) & 0.40 & $\begin{array}{l}\text { defense, response to wounding, inflammatory } \\
\text { response }\end{array}$ \\
\hline NM_000491 & complement component 1 , q subcomponent, b chain & 0.41 & $\begin{array}{l}\text { defense, response to wounding, inflammatory } \\
\text { response }\end{array}$ \\
\hline NM_001879 & mannan-binding lectin serine peptidase 1 & 0.44 & $\begin{array}{l}\text { defense, response to wounding, inflammatory } \\
\text { response }\end{array}$ \\
\hline NM_000892 & kallikrein b, plasma (fletcher factor) 1 & 0.44 & $\begin{array}{l}\text { defense, response to wounding, inflammatory } \\
\text { response }\end{array}$ \\
\hline NM_018647 & TNF receptor superfamily, member 19 & 0.39 & $\begin{array}{l}\text { inflammatory response, chemokine-chemokine } \\
\text { receptor interaction }\end{array}$ \\
\hline NM_000641 & interleukin 11 & 0.42 & $\begin{array}{l}\text { response to wounding, chemokine-chemokine } \\
\text { receptor interaction, Inflammatory response, cell } \\
\text { proliferation }\end{array}$ \\
\hline NM_002001 & fc fragment of IGE, receptor for alpha polypeptide & 3.00 & response to wounding, inflammatory response \\
\hline NM_020683 & adenosine $\mathrm{a} 3$ receptor & 0.45 & $\begin{array}{l}\text { response to wounding, inflammatory response, } \\
\text { defense }\end{array}$ \\
\hline NM_006691 & extracellular link domain containing 1 & 0.46 & response to wounding \\
\hline NM_005586 & myod family inhibitor & 2.01 & response to wounding \\
\hline NM_022161 & livin inhibitor-of-apotosis & 2.17 & response to wounding \\
\hline
\end{tabular}


II $\mathrm{Fe}_{2} \mathrm{O}_{3}$-NP regulated genes ( $>2$ fold)

\begin{tabular}{|c|c|c|c|}
\hline$\overline{\text { NM_002521 }}$ & natriuretic peptide precursor $b$ & 0.45 & renal system process \\
\hline NM_001955 & endothelin 1 & 0.49 & renal system process, cell proliferation \\
\hline XM_497590 & similar to 60 s ribosomal protein 129 (p23) & 2.04 & ribosomal processes \\
\hline XM_294581 & similar to ribosomal protein 136 & 2.33 & ribosomal processes \\
\hline XM_496991 & similar to 40 s ribosomal protein s 26 & 2.47 & ribosomal processes \\
\hline XM_377500 & similar to 40 s ribosomal protein s15 (rig protein) & 2.54 & ribosomal processes \\
\hline XM_497657 & similar to 40 s ribosomal protein s 16 & 2.64 & ribosomal processes \\
\hline XM_496362 & $\begin{array}{l}\text { similar to } 60 \text { s ribosomal protein } 16 \text { (taxreb107) } \\
\text { (neoplasm-related protein c140) }\end{array}$ & 2.71 & ribosomal processes \\
\hline XM_372759 & $\begin{array}{l}\text { similar to } 60 \text { s ribosomal protein } 110 \text { (qm protein) (tumor } \\
\text { suppressor qm) }\end{array}$ & 2.96 & ribosomal processes \\
\hline XM_927179 & similar to 40 s ribosomal protein s 26 & 2.98 & ribosomal processes \\
\hline XM_060417 & similar to ribosomal protein 136 & 3.40 & ribosomal processes \\
\hline XM_925952 & similar to 40 s ribosomal protein $\mathrm{s} 17$ & 3.53 & ribosomal processes \\
\hline XM_928025 & $\begin{array}{l}\text { similar to } 60 \mathrm{~s} \text { ribosomal protein } 110 \text { (qm protein) (tumor } \\
\text { suppressor qm) }\end{array}$ & 3.62 & ribosomal processes \\
\hline XM_376787 & ribosomal protein s26 pseudogene 10 & 3.64 & ribosomal processes \\
\hline XM_373343 & similar to 60 s ribosomal protein 132 & 3.96 & ribosomal processes \\
\hline XM_496363 & similar to ribosomal protein s2 & 4.54 & ribosomal processes \\
\hline XM_497357 & similar to ribosomal protein 110 & 7.71 & ribosomal processes \\
\hline
\end{tabular}

III $\mathrm{ZnO}-\mathrm{NP}$ regulated genes ( $>2$ fold)

\begin{tabular}{|c|c|c|c|}
\hline Gene ID & Gene Name & $\begin{array}{l}\text { Intensity } \\
\text { Ratio }\end{array}$ & Enriched Gene Ontology Term \\
\hline NM_000204 & complement factor $\mathrm{i}$ & 0.34 & activation of Immune response \\
\hline NM_001001895 & ubiquitin associated and sh3 domain containing, a & 0.45 & activation of Immune response \\
\hline NM_017773 & lymphocyte transmembrane adaptor 1 & 0.36 & activation of Immune response, inactivation of MAPK \\
\hline NM_021935 & prokineticin 2 & 0.44 & $\mathrm{Ca}^{2+}$ ion homeostasis \\
\hline NM_002425 & matrix metallopeptidase 10 (stromelysin 2) & 8.18 & $\mathrm{Ca}^{2+}$ ion homeostasis, inflammatory response \\
\hline NM_015063 & $\begin{array}{l}\text { solute carrier family } 8 \text { (sodium-calcium exchanger), } \\
\text { member } 2\end{array}$ & 2.29 & $\mathrm{Ca}^{2+}$ ion homeostasis, inflammatory response \\
\hline NM_001003954 & annexin a13 & 2.41 & $\mathrm{Ca}^{2+}$ ion homeostasis, inflammatory response \\
\hline NM_003585 & double c2-like domains, beta & 3.06 & $\mathrm{Ca}^{2+}$ ion homeostasis, inflammatory response \\
\hline NM_080388 & s100 calcium binding protein a16 & 2.37 & $\mathrm{Ca}^{2+}$ ion homeostasis, inflammatory response \\
\hline NM_007087 & calbindin $2,29 \mathrm{kda}$ (calretinin) & 2.43 & $\mathrm{Ca}^{2+}$ ion homeostasis, inflammatory response \\
\hline NM_002421 & matrix metallopeptidase 1 (interstitial collagenase) & 6.90 & $\mathrm{Ca}^{2+}$ ion homeostasis, inflammatory response \\
\hline NM_001669 & arylsulfatase d & 2.17 & $\mathrm{Ca}^{2+}$ ion homeostasis, inflammatory response \\
\hline NM_001039582 & $\begin{array}{l}\text { pregnancy upregulated non-ubiquitously expressed } \\
\text { cam kinase }\end{array}$ & 2.04 & $\mathrm{Ca}^{2+}$ ion homeostasis, inflammatory response \\
\hline NM_012076 & crumbs homolog 1 (drosophila) & 2.48 & $\mathrm{Ca}^{2+}$ ion homeostasis, inflammatory response \\
\hline NM_002590, & protocadherin 8 & 2.90 & $\mathrm{Ca}^{2+}$ ion homeostasis, inflammatory response \\
\hline NM_002770 & protease, serine, 2 (trypsin 2) & 2.78 & $\mathrm{Ca}^{2+}$ ion homeostasis, inflammatory response \\
\hline NM_018896 & $\begin{array}{l}\text { calcium channel, voltage-dependent, alpha } 1 \mathrm{~g} \\
\text { subunit }\end{array}$ & 2.28 & $\mathrm{Ca}^{2+}$ ion homeostasis, inflammatory response \\
\hline NM_001734 & complement component 1, s subcomponent & 3.96 & $\begin{array}{l}\mathrm{Ca}^{2+} \text { ion homeostasis, defense, inflammatory response, } \\
\text { response to stress }\end{array}$ \\
\hline NM_001257 & cadherin 13 , h-cadherin (heart) & 3.99 & $\mathrm{Ca}^{2+}$ ion homeostasis, inflammatory response, cell death \\
\hline NM_002739 & protein kinase c, gamma & 3.41 & $\begin{array}{l}\mathrm{Ca}^{2+} \text { ion homeostasis, inflammatory response, cell death, } \\
\text { response to stress, VEGF signaling. }\end{array}$ \\
\hline NM_000130 & coagulation factor v (proaccelerin, labile factor) & 2.68 & $\begin{array}{l}\mathrm{Ca}^{2+} \text { ion homeostasis, inflammatory response, response to } \\
\text { stress }\end{array}$ \\
\hline
\end{tabular}


III $\mathrm{ZnO}-\mathrm{NP}$ regulated genes ( $>2$ fold)

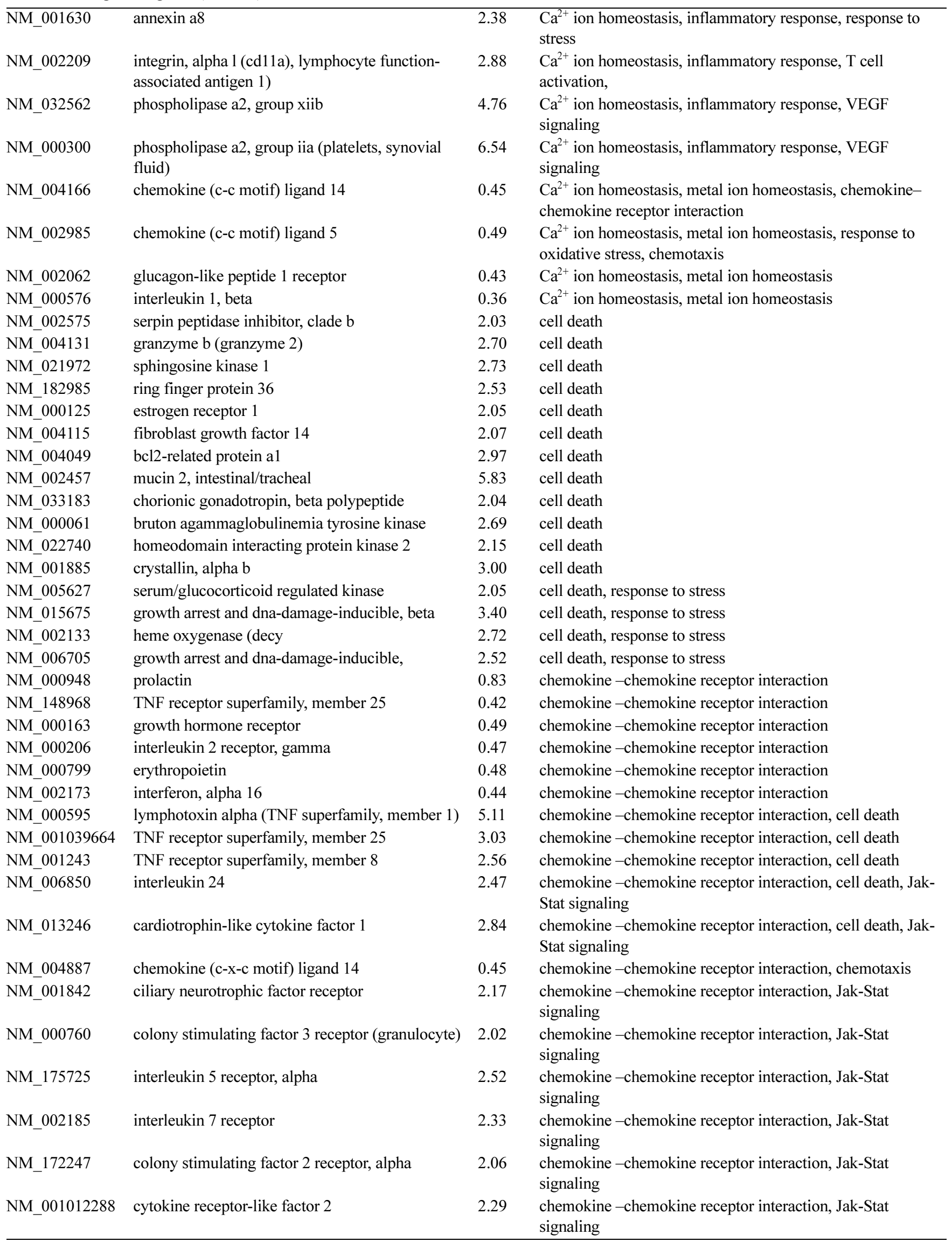


III $\mathrm{ZnO}-\mathrm{NP}$ regulated genes ( $>2$ fold)

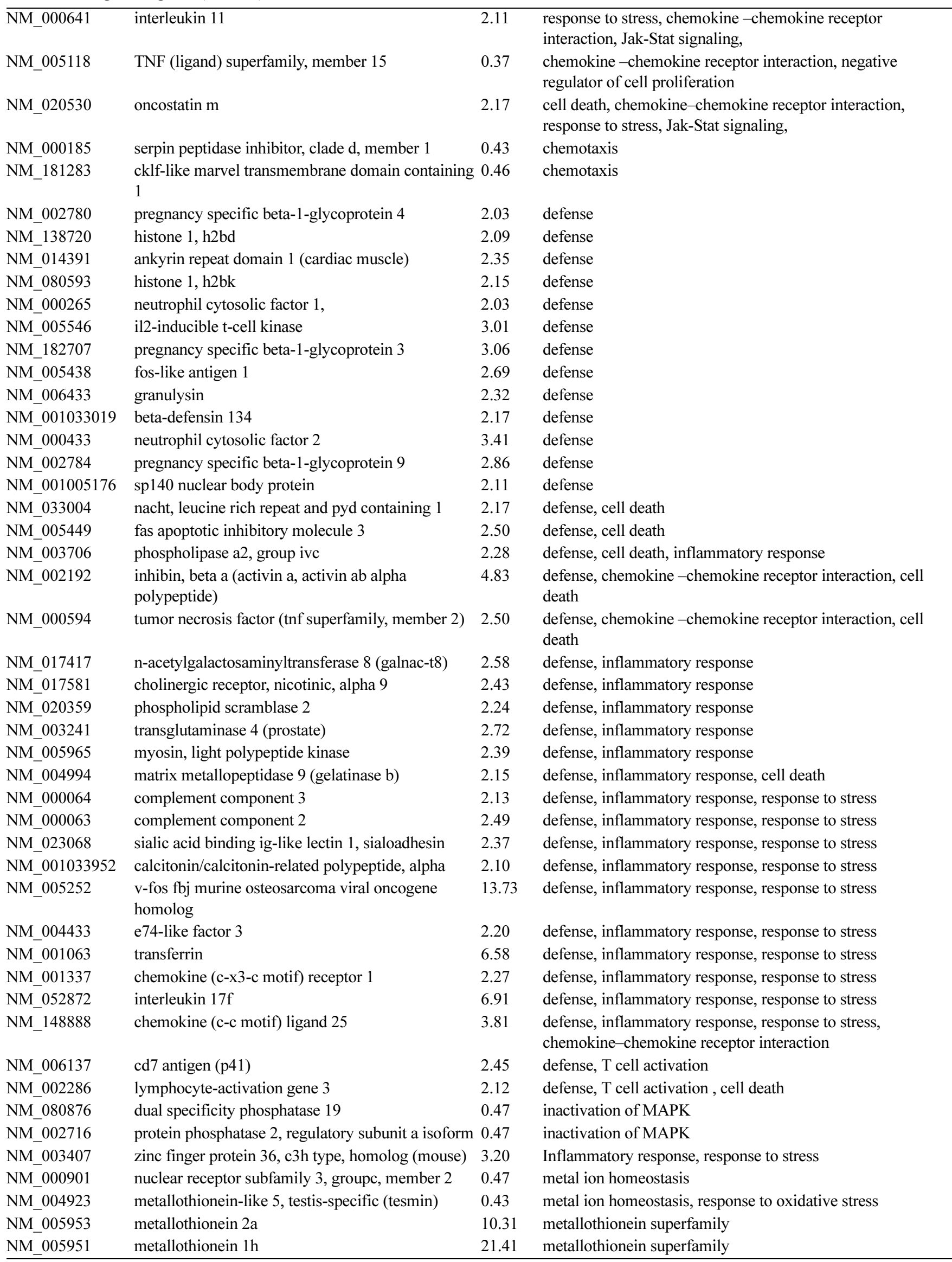


III $\mathrm{ZnO}-\mathrm{NP}$ regulated genes ( $>2$ fold)

\begin{tabular}{|c|c|c|c|}
\hline$\overline{\text { NM_005952 }}$ & metallothionein $1 \mathrm{x}$ & 14.36 & metallothionein superfamily \\
\hline NM_005950 & metallothionein $1 \mathrm{~g}$ & 36.32 & metallothionein superfamily \\
\hline NM_005947 & metallothionein $1 \mathrm{~b}$ (functional) & 16.53 & metallothionein superfamily \\
\hline NM_005949 & metallothionein 1f (functional) & 28.56 & metallothionein superfamily \\
\hline NM_080757 & chromosome 20 open reading frame 127 & 2.93 & metallothionein superfamily \\
\hline NM_175622 & metallothionein $1 \mathrm{j}$ (pseudogene) & 15.92 & metallothionein superfamily \\
\hline NM_-178543 & ectonucleotide pyrophosphatase 7 & 0.36 & negative regulation of cell proliferation \\
\hline NM_000914 & opioid receptor, mu 1 & 0.46 & negative regulation of cell proliferation \\
\hline NM_003641 & interferon induced transmembrane protein $1(9-27)$ & 0.49 & negative regulation of cell proliferation \\
\hline NM_000551 & von hippel-lindau tumor suppressor & 0.37 & negative regulation of cell proliferation \\
\hline NM_003225 & trefoil factor 1 & 0.44 & negative regulation of cell proliferation \\
\hline NM_001050 & somatostatin receptor 2 & 0.40 & negative regulation of cell proliferation \\
\hline NM_021146 & angiopoietin-like 7 & 0.45 & response to oxidative stress \\
\hline NM_000502 & eosinophil peroxidase & 0.45 & response to oxidative stress \\
\hline NM_000636 & superoxide dismutase 2 , mitochondrial & 0.18 & response to oxidative stress \\
\hline NM_000602 & serpin peptidase inhibitor, clade e & 2.96 & response to stress \\
\hline NM_001012964 & kallikrein 6 & 4.19 & response to stress \\
\hline NM_002155 & heat shock $70 \mathrm{kda}$ protein 6 & 66.61 & response to stress \\
\hline NM_015831 & acetylcholinesterase & 2.89 & response to stress \\
\hline NM_000020 & activin a receptor type ii-like 1 & 2.68 & response to stress \\
\hline NM_006308 & heat shock $27 \mathrm{kda}$ protein 3 & 5.40 & response to stress \\
\hline NM_012323 & $\begin{array}{l}\text { v-maf musculoaponeurotic fibrosarcoma oncogene } \\
\text { homolog } f\end{array}$ & 4.45 & response to stress \\
\hline NM_000798 & dopamine receptor $\mathrm{d} 5$ & 2.37 & response to stress \\
\hline NM_000088 & collagen, type i, alpha 1 & 2.09 & response to stress \\
\hline NM_000353 & tyrosine aminotransferase & 2.23 & response to stress \\
\hline NM_004931 & cd8 antigen, beta polypeptide 1 (p37) & 2.02 & $\mathrm{~T}$ cell activation \\
\hline NM_001964 & early growth response 1 & 5.04 & $\mathrm{~T}$ cell activation \\
\hline NM_014143 & cd274 antigen & 3.00 & $\mathrm{~T}$ cell activation \\
\hline NM_000193 & sonic hedgehog homolog (drosophila) & 3.47 & $\mathrm{~T}$ cell activation \\
\hline NM_012411 & protein tyrosine phosphatase, non-receptor type 22 & 3.12 & $\mathrm{~T}$ cell activation \\
\hline NM_005356 & lymphocyte-specific protein tyrosine kinase & 4.13 & $\mathrm{~T}$ cell activation, cell death \\
\hline NM_001025158 & cd74 antigen & 3.39 & T cell activation, cell death \\
\hline NM_021972 & sphingosine kinase 1 & 2.73 & VEGF signaling \\
\hline NM_002872 & rho family, small gtp binding protein rac2 & 2.42 & VEGF signaling \\
\hline NM_003975 & $\operatorname{sh} 2$ domain protein $2 \mathrm{a}$ & 2.18 & VEGF signaling \\
\hline
\end{tabular}

Table S2. Sequence of Primer pairs used in the study

\begin{tabular}{lll}
\hline Genes & Forward Primer (5'-3') & Reverse Primer (3'-5') \\
\hline Metallothionein 2a (MT2a) & ACTTGGCACAGCCCACAG & GACTCTAGCCGCCTCTTCAG \\
v-fos fbj murine osteosarcoma viral oncogene homolog & CCGGGGATAGCCTCTCTTAC & AGGTCCGGACTGGTCGAG \\
Interleukin17f (IL17f) & TGGCATCATCAATGAAAACC & TTCCTTGAGCATTGATGCAG \\
Chemokine cc motif ligand 15 (CCL15) & GCTTGTTGCTGTCCTTGGAT & GAGTGAACACGGGATGCTTT \\
Heat shock 70kDa protein 6 (HSPA6) & GAGATCTCGTCCATGGTGCT & TTGATGATCCGCAACACG \\
Matrix metallopeptidase 1 (MMP1) & TGGCATCATCAATGAAAACC & TTCCTTGAGCATTGATGCAG \\
Pregnancy specific beta-1-glycoprotein 8 (PSG1) & GACGCAGGATCCTACACCTT & GGTTAAGCTCACAGCCTCCA \\
Pregnancy specific beta-1-glycoprotein (PSG9) & AGCTGCCCATCCCCTACAT & GGCTCTGACCGTTTAGCCA \\
\hline
\end{tabular}

